GA-A24442

\title{
AUTOMATED BATCH CHARACTERIZATION OF ICF SHELLS WITH VISION-ENABLED OPTICAL MICROSCOPE SYSTEM
}

\author{
by \\ H. HUANG, R.B. STEPHENS, D.W. HILL, C. LYON, \\ A. NIKROO, and D.A. STEINMAN
}

SEPTEMBER 2003 


\section{DISCLAIMER}

This report was prepared as an account of work sponsored by an agency of the United States Government. Neither the United States Government nor any agency thereof, nor any of their employees, makes any warranty, express or implied, or assumes any legal liability or responsibility for the accuracy, completeness, or usefulness of any information, apparatus, product, or process disclosed, or represents that its use would not infringe privately owned rights. Reference herein to any specific commercial product, process, or service by trade name, trademark, manufacturer, or otherwise, does not necessarily constitute or imply its endorsement, recommendation, or favoring by the United States Government or any agency thereof. The views and opinions of authors expressed herein do not necessarily state or reflect those of the United States Government or any agency thereof. 


\title{
AUTOMATED BATCH CHARACTERIZATION OF ICF SHELLS WITH VISION-ENABLED OPTICAL MICROSCOPE SYSTEM
}

\author{
by \\ H. HUANG, R.B. STEPHENS, D.W. HILL, C. LYON, \\ A. NIKROO, and D.A. STEINMAN
}

This is a preprint of a paper presented at the 15th Target Fabricartion Specialists Meeting, Gleneden Beach, Oregon, June 1-5, 2003 and to be published in Fusion Science and Technology.

\author{
Work supported by \\ the U.S. Department of Energy \\ under Contract No. DE-AC03-01SF22260
}

\section{GENERAL ATOMICS PROJECT 30095 SEPTEMBER 2003}




\title{
AUTOMATED BATCH CHARACTERIZATION OF ICF SHELLS WITH VISION-ENABLED OPTICAL MICROSCOPE SYSTEM
}

\author{
H. Huang, R.B. Stephens, D.W. Hill, C. Lyon, A Nikroo, D.A. Steinman \\ General Atomics, P.O. Box 85608, San Diego, California 92186-5608 \\ huang @fusion.gat.com
}

\begin{abstract}
Inertial Confinement Fusion (ICF) shells are mesoscale objects with nano-scale dimensional and nanosurface finish requirements. Currently, the shell dimensions are measured by white-light interferometry and an image analysis method. These two methods complement each other and give a rather complete data set on a single shell. The process is, however, labor intensive. We have developed an automation routine to fully characterize a shell in one shot and perform unattended batch measurement. The method is useful to the ICF program both for production screening and for full characterization. It also has potential for Inertial Fusion Energy (IFE) power plant where half a million shells need to be processed daily. ${ }^{I}$
\end{abstract}

Common to both direct and indirect drive approach is a spherical capsule in which D-T fuel is layered at cryogenic temperature. A wide variety of processes and materials are used to make the shell mandrel. Fabrication induced imperfections must be thoroughly characterized as they directly impact target performance: RayleighTaylor instability would exponentially amplify any deviations from a perfect spherical geometry and quench the center hot spot in an implosion. ${ }^{2-4}$ In addition to the surface finish, commonly reported dimensional parameters are summarized in Table I.

Currently, we rely on white-light interference microscopy for highly accurate but very labor intensive measurements of various dimensions of these shells. ${ }^{5} \mathrm{~A}$ shell is mounted on a flat piece of glass, the height of each surface/interface and the off-centeredness of the interference fringes are recorded to calculate the OD, ID, wall thickness, and $4 \pi \Delta W$ (defined as $\sqrt{ }(3 / 2)$ or 1.22 times the $\Delta \mathrm{W}$ from the $2 \mathrm{D}$ projection). No information on OOR is available; as a result, a second image analysis method must be used in complement. An edge-focused image is recorded under backlighting condition to calculate OD and OOR, although no information on ID, Wall thickness, and $4 \pi \Delta \mathrm{W}$ is available through the image analysis approach. It is apparent that the two methods could be combined to provide a complete set of dimensional measurement for a single shell. There is a compelling need for an automated solution for routine characterization, especially for batch measurement of similar shells.

We identified a Nikon VMR3020 microscope [Fig. 1(a)] and adapted its software for our custom applications. The instrument has been programmed to do either single or batch measurement; and can repeat the measurement any number of times without operator intervention. For batch measurement, the shells are mounted onto a rectangular array of drilled holes $(1 / 3$ to $1 / 2$ the shell diameter) on a flat substrate. The automation routine detects the shell size, finds its edge, does autofocus, and conduct circumference scans of both the exterior and the interior surfaces (monitor view in Fig. 1(b) to retrieve information listed in Tables II, III and IV. The Nikon VMR 3020 microscope has a general purpose vision inspection system which can be customized for particular measurement through user defined "teaching files." Edge detection routine is used to find the location of the sharpest contrast change along the cursor arrow direction, as shown in Fig. 1(b) As the cursor moves along the surface contour, a collection of edge locations defines the exterior and interior surface respectively, as shown in Fig. 2. Circular and elliptical fits gives information such as those listed in Tables II, III, and IV. For example, the diameter of the best fit circle gives the shell diameter. The difference between the long and short axes gives (twice) the OOR. The off-centeredness of the interior and exterior surfaces is a measurement of the wall thickness variation, whereas the radius difference gives the wall thickness.It takes about 15 min to fully characterize 20 Omega-sized shells (once) using a Detailed measurement routine. For production screening of OD and circularity, 20 shells can be characterized (once) in less than one minute using a Quick measurement routine. The microscope reduces the focusing error due to manual operation (using the image analysis tool) and allows direct visualization of the shell wall [Fig. 1(b)]. So far we have successfully characterized shells made of PAMS, GDP, glass, and foam materials, as 
TABLE I. Definitions of Dimensional Parameters for ICF Shells

\begin{tabular}{llc}
\hline \multicolumn{1}{c}{ Parameter } & Definition & Typical Values for NIF Shell $(\mu \mathrm{m})$ \\
\hline OD & Outside Diameter & 2000 \\
Batch OD St.Dev. & $\begin{array}{l}\text { Standard Deviation of OD for a } \\
\text { particular batch }\end{array}$ & 6 \\
ID & Inside Diameter & 1966 \\
Batch ID St.Dev. & Standard Deviation of ID for a & 6 \\
particular batch & 2 \\
C (Circularity) & Average deviations from the best fit & \\
circle & Long axis of the best fit ellipse & $2001(1967)$ \\
SD & Short axis of the best fit ellipse & $1999(1965)$ \\
OOR (Out-Of-Round) & (LD-SD)/2 & 1 \\
NC (Non-Concentricity) & The distance between the centers of \\
& the best fit spheres for the interior & 0.2 \\
W (Wall Thickness) & and exterior surface. & 17 \\
$4 \pi \Delta W$ & (OD-ID)/2 & 0.5 \\
& Maximum wall thickness variation & \\
& in three dimensions, considering & \\
& only the effect of NC, or mode 1 & distortion. \\
\hline
\end{tabular}

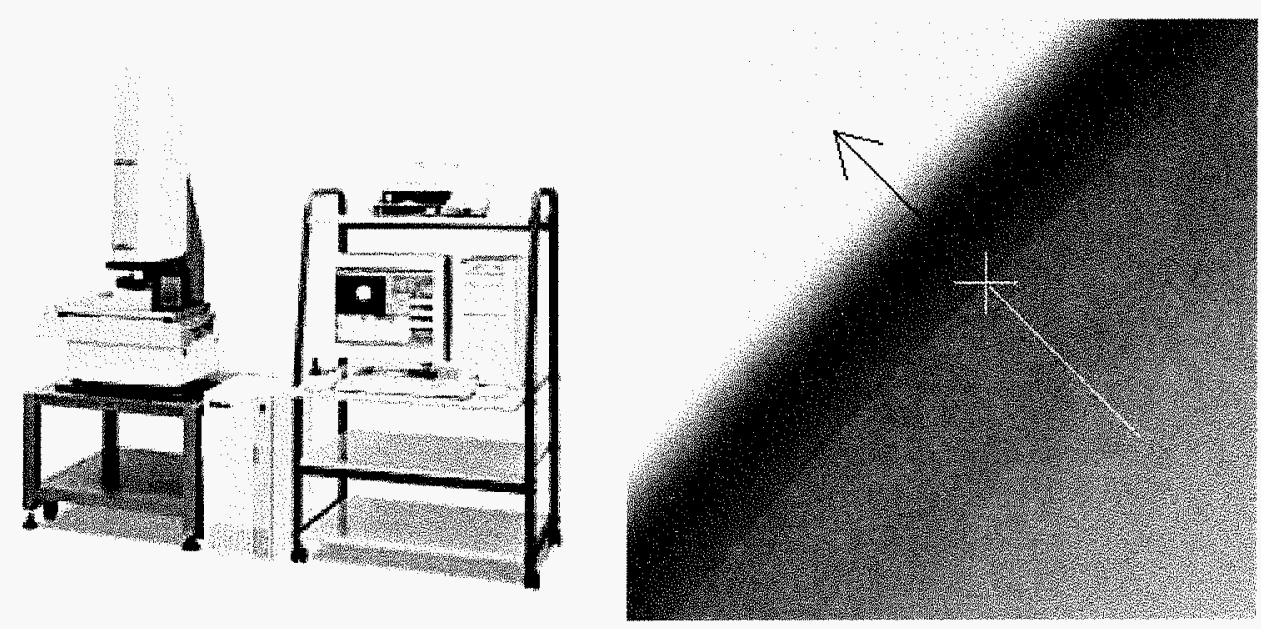

Fig. 1. (a) Nikon VMR 3020. (b) Cursor scans the interior edge of a PAMS shell.

well as fast ignition shells mounted on gold cone. The instrument requires pristine shell surface for good repeatability and is limited to the overall wall thickness if a multilayered shell is measured.

The calibration factors for the three most common PAMS mandrels, namely, NIF (2000 $\mu \mathrm{m}$ OD), Omega $(850 \mu \mathrm{m} \mathrm{OD})$ and Nova $(400 \mu \mathrm{m}$ OD), are listed in Tables II, III and IV where four sets of data are compared: (1) Detailed automation routine which gives OD, Batch OD St.Dev., C and OOR of the exterior surface, ID, Batch ID St.Dev., $\mathrm{C}$ and OOR of the interior surface, $\mathrm{NC}, \mathrm{W}$ and $4 \pi \Delta W$. (2) Quick automation routine which gives OD, Batch OD St.Dev., and $C$ of the exterior surface. (3) White-light interferometer which gives OD, Batch OD St.Dev., ID, Batch ID St.Dev., W and $4 \pi \Delta W$. (4) The image tool which gives OD, Batch OD St.Dev., and OOR of exterior surface. The repeatability values listed indicate instrument stability when measuring shells that are reasonably free of surface contamination. A calibration factor is to be added to a measurement value from the automated microscope to convert it to the corresponding value if the measurement method indicated in the bracket were used. Highlighted in bold are the calibration factors important to the ICF program and the measurement values we consider to be closest to reality.

Among the three types of shells, the Omega shells are by far the easiest to measure because of their usually pristine surface and the ease of handling. The NIF shells are very easy to handle, but are susceptible to an OOR problem discussed later. The Nova shells are very easy to measure, but painstaking to mount onto the array because the shells are too light-weighted and stick to vacuum wand. Simply degreasing the needle tip and ionizing the area are not sufficient to overcome static problem. One 
TABLE II. Automated Measurement Results for a Typical Batch of NIF Shells, Calibrated Against White-Light Interferometry (Interf.) and the Image Analysis Tool (Image)

\begin{tabular}{|c|c|c|c|c|}
\hline Parameter & Repeatability $(\mu \mathrm{m})$ & $\begin{array}{l}\text { Calibration factor } \\
(\mu \mathrm{m})\end{array}$ & $\begin{array}{l}\text { Measured Sample } \\
\text { Values }(\mu \mathrm{m})\end{array}$ & $\begin{array}{c}\text { Calibrated Sample } \\
\text { Values }(\mu \mathrm{m})\end{array}$ \\
\hline OD (Detailed) & 0.4 & $\begin{array}{l}+1.7 \text { (Interf.) } \\
+2.6 \text { (Image) }\end{array}$ & 1948.0 & $\begin{array}{l}1949.7 \text { (Interf.) } \\
1950.6 \text { (Image) }\end{array}$ \\
\hline OD (Quick) & 0.4 & $\begin{array}{l}+3.2 \text { (Interf.) } \\
+4.1 \text { (Image) }\end{array}$ & 1946.5 & $\begin{array}{l}1949.7 \text { (Interf.) } \\
1950.6 \text { (Image) }\end{array}$ \\
\hline $\begin{array}{l}\text { Batch St.Dev. OD } \\
\text { (Detailed or Quick) }\end{array}$ & 0.2 & $\begin{array}{l}+0.5 \text { (Interf.) } \\
-0.3 \text { (Image) }\end{array}$ & 10.2 & $\begin{array}{l}10.7 \text { (Interf.) } \\
9.9 \text { (Image) }\end{array}$ \\
\hline $\begin{array}{l}\text { Circularity-Exterior } \\
\text { (Detailed \& Quick) }\end{array}$ & 0.2 & $\begin{array}{l}\text { N/A (Interf.) } \\
+0.0 \text { (Quick) }\end{array}$ & 2.8 & 2.8 \\
\hline $\begin{array}{l}\text { OOR-Exterior } \\
\text { (Detailed) }\end{array}$ & $\begin{array}{c}\text { *Varies } \\
\text { (*Do not use) }\end{array}$ & $\begin{array}{c}\text { N/A**(Image) } \\
\text { (**Surface Dep.) }\end{array}$ & N/A & N/A \\
\hline ID (Detailed) & 0.4 & +5.0 (Interf.) & 1910.1 & 1915.1 \\
\hline $\begin{array}{l}\text { Batch St.Dev. ID } \\
\text { (Detailed) }\end{array}$ & 0.2 & +0.3 (Interf.) & 10.8 & 11.1 \\
\hline $\begin{array}{l}\text { Circularity-Interior } \\
\text { (Detailed) }\end{array}$ & 0.2 & N/A (Interf.) & 1.5 & 1.5 \\
\hline $\begin{array}{l}\text { OOR-Interior } \\
\text { (Detailed) }\end{array}$ & $\begin{array}{c}0.2^{*} \\
\text { (*Use with caution) }\end{array}$ & $\begin{array}{c}-0.1 \text { (Image) })^{* *} \\
(* * \text { Exterior) }\end{array}$ & 1.1 & 1.0 \\
\hline NC (Detailed) & 0.2 & -0.3 (Interf.) & 0.5 & 0.2 \\
\hline Wall (Detailed) & 0.2 & -1.7 (Interf.) & 19.0 & 17.3 \\
\hline $4 \pi \Delta W$ (Detailed) & 0.2 & -0.8 (Interf.) & 1.3 & 0.5 \\
\hline
\end{tabular}

TABLE III. Automated Measurement Results for a Typical Batch of OMEGA Shells, Calibrated Against White-Light Interferometry (Interf.) and the Image Analysis Tool (Image)

\begin{tabular}{|c|c|c|c|c|}
\hline Parameter & Repeatability $(\mu \mathrm{m})$ & $\begin{array}{l}\text { Calibration factor } \\
(\mu \mathrm{m})\end{array}$ & $\begin{array}{l}\text { Measured Sample } \\
\text { Values }(\mu \mathrm{m})\end{array}$ & $\begin{array}{c}\text { Calibrated Sample } \\
\text { Values }(\mu \mathrm{m})\end{array}$ \\
\hline OD (Detailed) & 0.1 & $\begin{array}{l}-1.4 \text { (Interf.) } \\
-1.0 \text { (Image) }\end{array}$ & 908.4 & $\begin{array}{l}907.0 \text { (Interf.) } \\
907.4 \text { (Image) }\end{array}$ \\
\hline OD (Quick) & 0.1 & $\begin{array}{l}+2.1 \text { (Interf.) } \\
+2.5 \text { (Image) }\end{array}$ & 904.9 & $\begin{array}{l}907.0 \text { (Interf.) } \\
907.4 \text { (Image) }\end{array}$ \\
\hline $\begin{array}{l}\text { Batch St.Dev. OD } \\
\text { (Detailed or Quick) }\end{array}$ & 0.1 & $\begin{array}{l}+0.2 \text { (Interf.) } \\
-0.2 \text { (Image) }\end{array}$ & 6.7 & $\begin{array}{l}6.9 \text { (Interf.) } \\
6.5 \text { (Image) }\end{array}$ \\
\hline $\begin{array}{l}\text { Circularity-Exterior } \\
\text { (Detailed \& Quick) }\end{array}$ & 0.2 & $\begin{array}{l}\text { N/A (Interf.) } \\
+0.0 \text { (Quick) }\end{array}$ & 1.7 & 1.7 \\
\hline $\begin{array}{l}\text { OOR-Exterior } \\
\text { (Detailed) }\end{array}$ & $\begin{array}{c}\text { Varies } \\
\text { (*Do not use) }\end{array}$ & $\begin{array}{c}\text { N/A** (Image) } \\
(* * \text { Surface Dep.) }\end{array}$ & N/A & N/A \\
\hline ID (Detailed) & 0.1 & +1.2 (Interf.) & 881.9 & 883.1 \\
\hline $\begin{array}{l}\text { Batch St.Dev. ID } \\
\text { (Detailed) }\end{array}$ & 0.1 & +0.0 (Interf.) & 7.2 & 7.2 \\
\hline $\begin{array}{l}\text { Circularity-Interior } \\
\text { (Detailed) }\end{array}$ & 0.1 & N/A (Interf.) & 1.3 & 1.3 \\
\hline $\begin{array}{l}\text { OOR-Interior } \\
\text { (Detailed) }\end{array}$ & $\begin{array}{c}0.2^{*} \\
\text { (*Use with caution) }\end{array}$ & $\begin{array}{c}-0.3 \text { (Image })^{* *} \\
(* * \text { Exterior })\end{array}$ & 0.8 & 0.5 \\
\hline NC (Detailed) & 0.1 & -0.3 (Interf.) & 0.7 & 0.4 \\
\hline Wall (Detailed) & 0.1 & -1.3 (Interf.) & 13.2 & 11.9 \\
\hline $4 \pi \Delta W$ (Detailed) & 0.2 & -0.8 (Interf.) & 1.7 & 0.9 \\
\hline
\end{tabular}

must use a particularly small needle with a beveled tip to release these shells by gently nudging on the array substrate.

The automated microscope is very robust for OD, ID and wall thickness measurements. The calibrations factors are explainable through physical phenomena such as refraction, diffraction and the non-parallel-ness of the light beam. There is a software problem with the elliptical fit routine that can sometimes lead to erroneous OOR result even when the data set is normal. We are working with Nikon to resolve this problem. In the interim period, the user is advised to use the OOR values measured on the interior surface for an estimation of the mode 2 quality. This is because the edge contrast is much sharper due to superimposed phase contrast; the elliptical fit problem is dramatically reduced when the raw data set is less jittery, 
TABLE IV. Automated Measurement Results for a Typical Batch of Nova Shells, Calibrated Against White-Light Interferometry (Interf.) and the Image Analysis Tool (Image)

\begin{tabular}{|c|c|c|c|c|}
\hline Parameter & Repeatability $(\mu \mathrm{m})$ & $\begin{array}{c}\text { Calibration factor } \\
(\mu \mathrm{m})\end{array}$ & $\begin{array}{c}\text { Measured Sample } \\
\text { Values }(\mu \mathrm{m})\end{array}$ & $\begin{array}{c}\text { Calibrated Sample } \\
\text { Values }(\mu \mathrm{m})\end{array}$ \\
\hline OD (Detailed) & 0.1 & $\begin{array}{l}-1.2 \text { (Interf.) } \\
-0.8 \text { (Image) }\end{array}$ & 455.5 & $\begin{array}{l}\mathbf{4 5 4 . 3} \text { (Interf.) } \\
454.7 \text { (Image) }\end{array}$ \\
\hline OD (Quick) & 0.1 & $\begin{array}{l}-0.9 \text { (Interf.) } \\
-0.5 \text { (Image) }\end{array}$ & 455.2 & $\begin{array}{l}454.3 \text { (Interf.) } \\
454.7 \text { (Image) }\end{array}$ \\
\hline $\begin{array}{l}\text { Batch St.Dev. OD } \\
\text { (Detailed or Quick) }\end{array}$ & 0.1 & $\begin{array}{l}+0.2 \text { (Interf.) } \\
+0.0 \text { (Image) }\end{array}$ & 3.2 & $\begin{array}{l}3.4 \text { (Interf.) } \\
3.2 \text { (Image) }\end{array}$ \\
\hline $\begin{array}{l}\text { Circularity-Exterior } \\
\text { (Detailed \& Quick) }\end{array}$ & 0.1 & $\begin{array}{l}\text { N/A (Interf.) } \\
+0.2 \text { (Quick) }\end{array}$ & 1.5 & 1.5 \\
\hline $\begin{array}{l}\text { OOR-Exterior } \\
\text { (Detailed) }\end{array}$ & $\begin{array}{c}\text { Varies } \\
\text { (*Do not use) }\end{array}$ & $\begin{array}{c}\text { N/A (Image) } \\
\text { (**Surface Dep.) }\end{array}$ & $\mathrm{N} / \mathrm{A}$ & N/A \\
\hline ID (Detailed) & 0.1 & +0.6 (Interf.) & 443.5 & 444.1 \\
\hline $\begin{array}{l}\text { Batch St.Dev. ID } \\
\text { (Detailed) }\end{array}$ & 0.1 & +0.2 (Interf.) & 3.7 & 3.9 \\
\hline $\begin{array}{l}\text { Circularity-Interior } \\
\text { (Detailed) }\end{array}$ & 0.1 & N/A (Interf.) & 1.2 & 1.2 \\
\hline $\begin{array}{l}\text { OOR-Interior } \\
\text { (Detailed) }\end{array}$ & $\begin{array}{c}0.2^{*} \\
\text { (*Use with caution) }\end{array}$ & $\begin{array}{c}-0.1 \text { (Image) })^{* *} \\
(* * \text { Exterior) }\end{array}$ & 0.7 & 0.6 \\
\hline NC (Detailed) & 0.1 & -0.3 (Interf.) & 0.4 & 0.1 \\
\hline Wall (Detailed) & 0.1 & -0.9 (Interf.) & 6.9 & 6.0 \\
\hline $4 \pi \Delta \mathrm{W}$ (Detailed) & 0.2 & -0.9 (Interf.) & 1.2 & 0.3 \\
\hline
\end{tabular}

as shown in Fig. 2. The graphs also show that the elliptical shape of the sample can be clearly measured with this technique. It is worth noting that, if a shell is physically rotated $90^{\circ}$, the elliptical profiles rotate with the same angle with the sample, therefore the elliptical shape is a direct measurement of the sample profile and not an artifact of illumination due to the presence of polarizers in thre optical system.

In conclusion, we have developed an automated method to characterize shell batches, and obtained the calibration factors for three commonly encountered PAMS shells. All parameters can be consistently measured with predetermined calibration factors, with the exception of the exterior surface OOR.

\section{ACKNOWLEDGMENTS}

Work supported by the U.S. Department of Energy under Contract No. DE-AC03-01SF22260. The authors would also like to thank Mark Byra of A.G. Heinze for his technical support on the Nikon microscope.

\section{REFERENCES}

1. W.J. HOGAN, "Energy from Inertial Fusion," International Atomic Energy Agency (1995).

2. S.A. LETTS, E.M. FEARON, S.R. BUCKLEY, M.D. SACULLA, L.M. ALLISON, R. COOK, "Fabrication of Polymer Shells Using a Depolymerizable Mandrel," Fusion Technology 28 1797-1802 (1995).

3. J.D. LINDL, "Inertial Confinement Fusion: The Quest for Ignition and Energy Gain Using Indirect Drive," (1997).

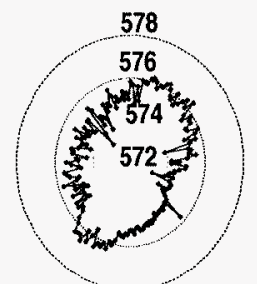

(a) Exterior Radius

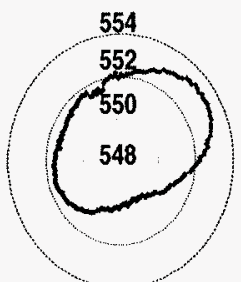

(b) Interior Radius
Fig. 2. The deviations from a $2000 \mu \mathrm{m}$ diameter circle were greatly amplified to present the minor distortions on a visible scale. The diagrams cover a radius range of $6 \mu \mathrm{m}$. Two effects are notable. (1) While both data sets are taken with the same sample orientation, the interior profile appears to have rotated a few degrees and is offcentered. This is because the center of the best fit circle for the exterior surface was used to define the polar plot center in both plots. For a microencapsulated shell, the interior surface does not necessary aligns itself to the same orientation or the center of the exterior surface, both of which would affect wall thickness uniformity. (2) The interior profile is much less jittery due to enhanced phasecontrast.

4. M. HERRMANN, M. TABAK, D. CALLAHANMILLER, J. LINDL, "Surface Finish Requirements for IFE", a recent presentation to the ICF community with work performed at LLNL under DOE contract \# W-7405Eng-48.

5. R.B. STEPHENS and M. WITTMAN,"Laser Fusion Target Shell Wall Thickness from Interference Fringe Shape Analysis," J.Vac. Sci. \& Technol. A12 1302 (1994). 